\title{
Myocardial infarction in a patient with left ventricular noncompaction: a case report
}

This article was published in the following Dove Press journal:

International Journal of General Medicine

30 July 2012

Number of times this article has been viewed

\author{
Mehrnoush Toufan' \\ Roya Shahvalizadeh' \\ Majid Khalili² \\ 'Cardiovascular Research Center, \\ Tabriz University of Medical Sciences, \\ Tabriz, Iran; ${ }^{2}$ Azerbaijan National \\ Academy of Sciences, Baku, Azerbaijan
}

Correspondence: Majid Khalil

Azerbaijan National Academy of Sciences,

9 B Vaxabzade Street,

Baku AZI I4I, Azerbaijan

Tel/Fax +994 I2 4923529

Email khalili876@gmail.com
Abstract: We describe a 73-year-old male patient with left ventricular noncompaction (LVNC) who was diagnosed with acute myocardial infarction (MI), three-vessel coronary artery disease, a fresh intraventricular thrombus, and mitral regurgitation. He was treated with full anticoagulant therapy, coronary artery bypass grafting, and mitral valve repair. This case adds to a small but growing literature showing association between LVNC and MI and/or coronary artery disease. We suggest that patients with LVNC could be considered at heightened risk for MI, and the two conditions might have a common genetic underpinning in some cases.

Keywords: myocardium, development, cardiomyopathy, echocardiography

\section{Introduction}

Left ventricular noncompaction (LVNC) arises during development of the myocardium after week 18 of gestation, and is sometimes associated with other congenital cardiac abnormalities. ${ }^{1,2}$ It is characterized by deep endothelium-lined trabeculations, identifiable by colored Doppler imaging, ${ }^{3}$ that are continuous with the lumen of the left ventricle and give the ventricular wall a two-layered appearance (noncompacted and compacted). Echocardiography showing recesses in the wall, especially around the apex, is diagnostic for this type of cardiomyopathy, though magnetic resonance imaging is useful when no echocardiogram is available. ${ }^{4,5}$ Nevertheless, LVNC can be mistaken for other conditions, such as dilated, hypertrophic, and apical hypertrophic cardiomyopathies, ${ }^{6}$ or infiltrative disease such as cardiac amyloidosis, ${ }^{7}$ and LV opacification might help to confirm the diagnosis. ${ }^{7}$ The incidence of LVNC is uncertain, ${ }^{3}$ but has been estimated at 0.12 per 100,000 in children younger than 10 years. ${ }^{8}$

As with other cardiomyopathies, depressed systolic and diastolic functions are typical, and tachyarrhythmias are common; there is a predisposition to arterial embolism. ${ }^{8}$ Thus, patients are likely to complain of breathlessness, fatigue, and peripheral edema. Electrocardiogram features include extreme QRS voltages, isolated $\mathrm{T}$ waves, and evidence of Wolff-Parkinson-White syndrome, with premature contraction of both atria and ventricles. ${ }^{9}$

LVNC is familial and is now considered a primary genetic cardiomyopathy, though phenotypic features can differ among members of the same family. Patient cohorts show a high frequency of mutation in the gene Cypher/ZASP, which encodes a component of the $\mathrm{Z}$ line of cardiac muscle; histologically, individuals with Cypher/ ZASP mutations show disordered muscular cytoskeletons. ${ }^{10}$ Other genes reported to be mutated in cases of LVNC include those encoding myoadenylate deaminase, ${ }^{11}$ 


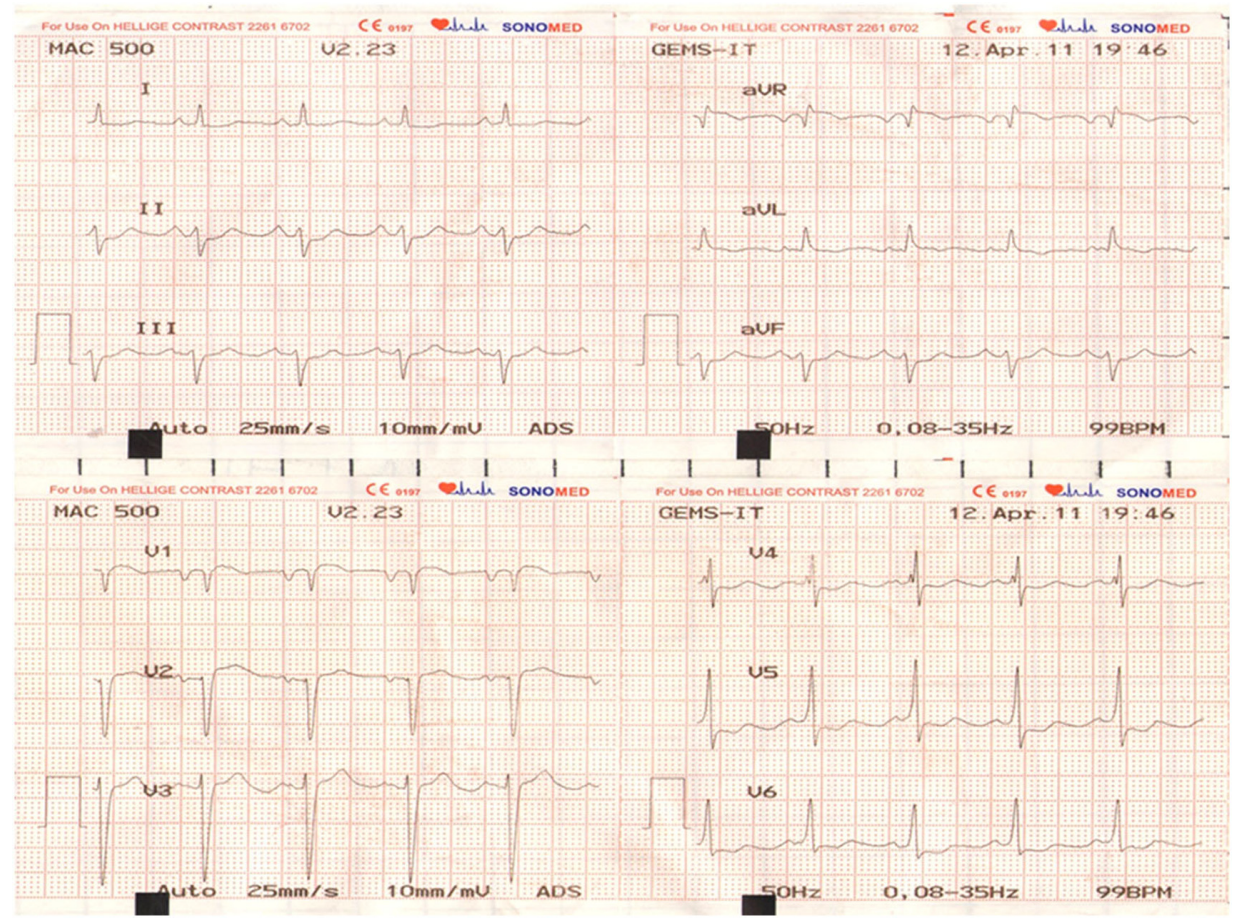

Figure I Electrocardiogram of the patient with nonspecific changes; left axis deviation of QRS, ST-segment elevation in augmented vector right (aVR) and VI, poor R-wave progression in right precordial leads, ST-segment depression in left precordial leads as evidence of ischemia.

cytochrome $\mathrm{P} 4502 \mathrm{C} 9,{ }^{12}$ cardiac $\alpha$-actin, ${ }^{13}$ troponin $\mathrm{T},{ }^{14}$ and other sarcomere-related proteins. ${ }^{15-17}$

We describe a case of LVNC associated with myocardial infarction (MI) in a 73-year-old man.

\section{Case report}

A 73-year-old man was admitted with typical chest pain and exertional dyspnea (New York Heart Association functional class III), with the diagnosis of acute MI. Clinical examination revealed an apical systolic murmur. Figure 1 shows an electrocardiogram of the patient, demonstrating nonspecific changes: left-axis deviation of QRS, ST elevation in aVR and $\mathrm{V}_{1}$, poor R-wave progression in right precordial leads, $\mathrm{ST}$ depression in left precordial leads as evidence of ischemia. Transthoracic echocardiography revealed apical left ventricular hypertrabeculation characteristic of left ventricular
A

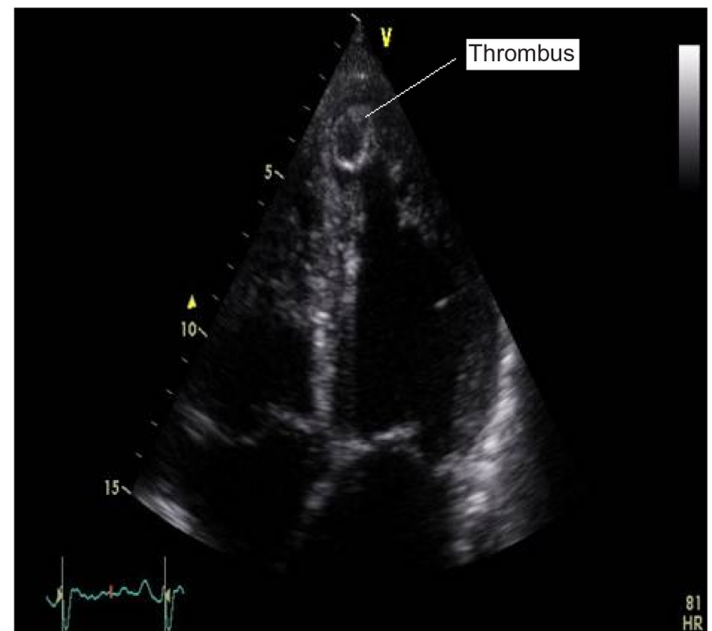

B

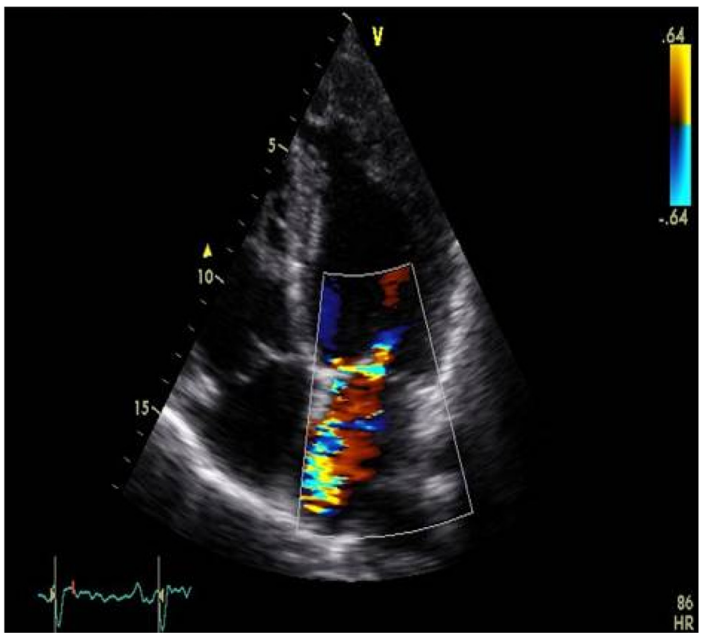

Figure 2 Transthoracic echocardiography showing apical akinesis with increased trabecularization and thrombus (A), and color Doppler echocardiography revealing severe mitral regurgitation (B). Apical thrombus is shown by arrow in $\mathbf{A}$. 
noncompaction, akinesis in a small area of the apex, and fresh thrombus (Figure 2A), and color Doppler echocardiography showed partially flail mitral valve with severe mitral regurgitation (MR) (Figure 2B). Coronary angiography showed three-vessel coronary artery disease; the patient received full anticoagulant therapy. Follow-up transthoracic (Figure 3A) and transesophageal (Figure 3B) echocardiography 10 days later showed resolving apical thrombus.

The patient underwent coronary artery bypass grafting and mitral valve (MV) repair. The patient received three grafts, and the MV was repaired by insertion of an annuloplasty ring in MV annular position. He was discharged 8 days after operation with residual mild MR, and left ventricular ejection fraction of $35 \%$ indicating a good surgical result.

\section{Discussion}

LVNC was first identified in a 33-year-old woman in 1984 by Engberding and Bender ${ }^{18}$ who supposed that the trabeculae were sinusoids. It was long thought to be predominantly a disease of children, but by the late 1990s there were
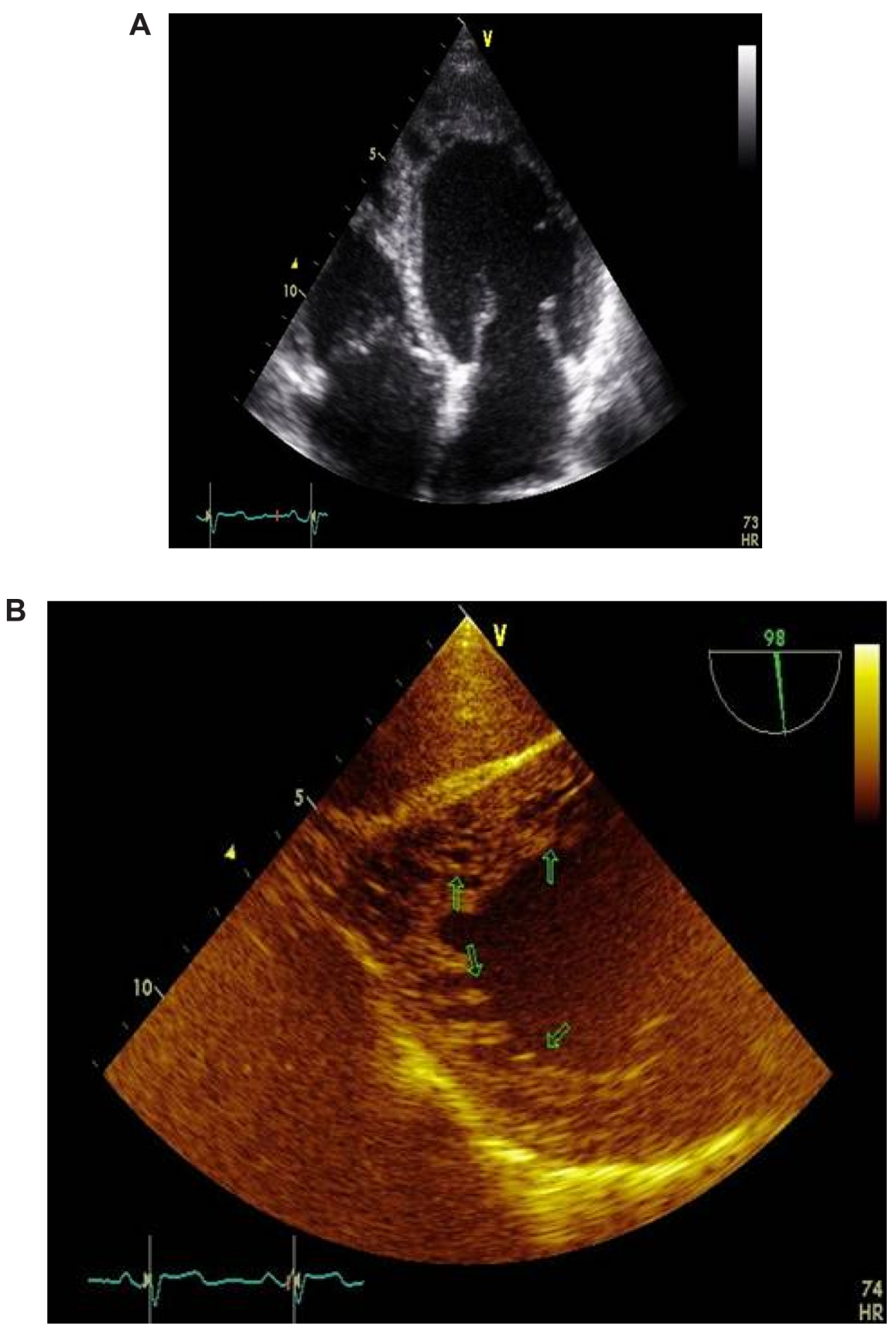

Figure 3 Follow-up transthoracic (A) and transesophageal (B) echocardiography showing resolution of apical thrombus. 
increasing numbers of reports in adults. ${ }^{19}$ Some authorities now suppose it could be more common than hitherto suspected because it may have been misdiagnosed in the past. ${ }^{4}$ Magnetic resonance imaging (MRI) is now considered the gold standard for the diagnosis of this entity. However, MRI is usually used when results of other imaging modalities are not definitive. ${ }^{20}$ In the present report, LVNC was diagnosed based on the echocardiographic assessment; therefore, MRI was not applied. Moreover, LVNC is usually managed in the same way as other cardiomyopathies; beta-blockers, aspirin, and angiotensin-converting enzyme inhibitors are customarily used; installation of a pacemaker is an option if the risk of arrhythmia is high. ${ }^{8}$ In the case of our patient, these approaches to management were deemed unnecessary.

LVNC can be associated with other cardiac and neuromuscular pathologies. ${ }^{21,22}$ Mitral regurgitation and coronary heart disease have been reported in some patients. ${ }^{23}$ Although association of LVNC with coronary heart disease is said to be rare ${ }^{24}$ we found four recent reports of association between LVNC and subclinical or acute $\mathrm{MI},{ }^{25-28}$ and it is possible that this association has previously been undiagnosed. The recognized pathogenic consequences of LVNC could predispose to MI, and our patient may exemplify such predisposition. Moreover, LVNC may affect the progression of remodeling in patients with MI and may worsen their prognosis. Further studies are recommended to focus on this hypothesis.

It is worth considering the possibility of common genetic underpinning of LVNC and MI in some cases. For instance, the myocardial adenylate deaminase C34T genotype predicted mortality in some patients with histories of $\mathrm{MI},{ }^{29}$ and there are suggestions of association between MI and both cytochrome $\mathrm{P} 4502 \mathrm{C} 9$ activity and sarcomere-related proteins such as the calcium-binding protein S100A. ${ }^{30,31}$ One may suggest that when LVNC is diagnosed and the genes for one or more of these proteins are mutated, an increased risk for MI should be suspected. However, the present report lacks the genetic evaluation, and such workup is recommended in future reports of MI in patients with LVNC.

\section{Disclosure}

The authors report no conflicts of interest in this work.

\section{References}

1. Espinola-Zavaleta N, Soto ME, Castellanos LM, Játiva-Chávez S, Keirns C. Non-compacted cardiomyopathy: clinical-echocardiographic study. Cardiovasc Ultrasound. 2006;4:35

2. Sakan H, Okayama S, Uemura S, et al. Atrial right-to-left shunt without pulmonary hypertension in a patient with biventricular non-compaction cardiomyopathy accompanied by ventricular and atrial septal defects. Intern Med. 2011;50(16):1747-1751.
3. Baumhäkel M, Janzen I, Kindermann M, Schneider G, Hennen B, Böhm M. Images in cardiovascular medicine. Cardiac imaging in isolated noncompaction of ventricular myocardium. Circulation. 2002;106(5):e16-e17.

4. McCrohon JA, Richmond DR, Pennell DJ, Mohiaddin RH. Images in cardiovascular medicine. Isolated noncompaction of the myocardium: a rarity or missed diagnosis? Circulation. 2002;106(6):e22-e23.

5. Weiford BC, Subbarao VD, Mulhern KM. Noncompaction of the ventricular myocardium. Circulation. 2004;109(24):2965-2971.

6. Yusuf SW, Bathina JD, Banchs J, Mouhayar EN, Daher IN. Apical hypertrophic cardiomyopathy. World J Cardiol. 2011;3(7):256-259.

7. Buss SJ, Mereles D, Katus HA, Hardt SE. Left ventricular non-compaction cardiomyopathy mimicking an infiltrative cardiac disease. Int J Cardiol. 2011;147(3):e41-e43.

8. Botto LD. Left ventricular noncompaction. Orphanet Encyclopedia. 2004 Available from: http://www.orpha.net/data/patho/GB/uk-LVNC. pdf. Accessed November 15, 2011.

9. Weiford BC, Subbarao VD, Mulhern KM. Noncompaction of the ventricular myocardium. Circulation. 2004;109(24):2965-2971.

10. Vatta M, Mohapatra B, Jimenez S, et al. Mutations in Cypher/ ZASP in patients with dilated cardiomyopathy and left ventricular non-compaction. J Am Coll Cardiol. 2003;42(11):2014-2027.

11. Finsterer J, Schoser B, Stöllberger C. Myoadenylate-deaminase gene mutation associated with left ventricular hypertrabeculation/ non-compaction. Acta Cardiol. 2004;59(4):453-456.

12. Bohrer T, Klein HG, Elert O. Left ventricular non-compaction associated with a genetic variant of the CYP2C9 gene. Heart Lung Circ. 2006; 15(4):269-271

13. Monserrat L, Hermida-Prieto M, Fernandez X, et al. Mutation in the alpha-cardiac actin gene associated with apical hypertrophic cardiomyopathy, left ventricular non-compaction, and septal defects. Eur Heart J. 2007;28(16):1953-1961.

14. Luedde M, Ehlermann P, Weichenhan D, et al. Severe familial left ventricular non-compaction cardiomyopathy due to a novel troponin T (TNNT2) mutation. Cardiovasc Res. 2010;86(3):452-460.

15. Ripoll Vera T, Monserrat Iglesias L, Hermida Prieto M, et al. The R $820 \mathrm{~W}$ mutation in the MYBPC3 gene, associated with hypertrophic cardiomyopathy in cats, causes hypertrophic cardiomyopathy and left ventricular non-compaction in humans. Int J Cardiol. 2010;145(2):405-407.

16. Marziliano N, Mannarino S, Nespoli L, et al. Barth syndrome associated with compound hemizygosity and heterozygosity of the TAZ and LDB3 genes. Am J Med Genet A. 2007;143A(9):907-915.

17. Pantazis AA, Elliott PM. Left ventricular noncompaction. Curr Opin Cardiol. 2009;24(3):209-213.

18. Engberding R, Bender F. Identification of a rare congenital anomaly of the myocardium by two-dimensional echocardiography: persistence of isolated myocardial sinusoids. Am J Cardiol. 1984;53(11): 1733-1734

19. Agmon Y, Connolly HM, Olson LJ, Khandheria BK, Seward JB. Noncompaction of the ventricular myocardium. JAm Soc Echocardiogr. 1999;12(10):859-863.

20. Danik S, Singh J. Sudden cardiac risk assessment. In: Auricchio A, Singh J, Rademakers FE, editors. Cardiac Imaging in Electrophysiology. London: Springer-Verlag; 2012:277-291.

21. Stollberger C, Finsterer J, Blazek G. Left ventricular hypertrabeculation/noncompaction and association with additional cardiac abnormalities and neuromuscular disorders. Am J Cardiol. 2002;90(8): 899-902.

22. Murphy RT, Thaman R, Blanes JG, et al. Natural history and familial characteristics of isolated left ventricular non-compaction. Eur Heart J. 2005;26(2):187-192.

23. Salati M, Di Mauro A, Bregasi A, Mattioli R. Coronary artery bypass graft and mitral valvuloplasty in a patient with isolated ventricular non-compaction. Interact Cardiovasc Thorac Surg. 2010;11(3): 354-356.

24. Panduranga P, Mukhaini MK. Left-ventricular non-compaction with coronary artery disease. Int J Cardiol. 2011;150(1):e37-e39. 
25. Gabrielli FA, Lombardo A, Natale L, et al. Myocardial infarction in isolated ventricular non-compaction: contrast echo and MRI. Int $J$ Cardiol. 2006;111(2):315-317.

26. Swinkels BM, Boersma LVA, Rensing BJ, Jaarsma W. Isolated left ventricular noncompaction in a patient presenting with a subacute myocardial infarction. Neth Heart J. 2007;15(3):109-111.

27. Correia E, Santos LF, Rodrigues B, Gama P, Cabral C, Santos O. Noncompaction of the myocardium in a patient with acute myocardial infarction. Arq Bras Cardiol. 2010;94(5):e62-e64, e125-e127.

28. Fettouhi H, Tamdy A, Ellouali F, Doghmi N, Zarzur J, Cherti M. Convulsives crisis revealing left-ventricular non-compaction with apical myocardial infarction [French]. Ann Cardiol Angeiol (Paris). 2011;60(3):159-164.
29. Collins RP, Palmer BR, Pilbrow AP, et al. Evaluation of AMPD1 C34T genotype as a predictor of mortality in heart failure and post-myocardial infarction patients. Am Heart J. 2006;152(2):312-320.

30. Visser LE, van Schaik RH, Jan Danser AH, et al. The risk of myocardial infarction in patients with reduced activity of cytochrome P450 2 C9. Pharmacogenet Genomics. 2007;17(7):473-479.

31. Rohde D, Ritterhoff J, Voelkers M, Katus HA, Parker TG, Most P. S100A1: a multifaceted therapeutic target in cardiovascular disease. J Cardiovasc Transl Res. 2010;3(5):525-537.
International Journal of General Medicine

\section{Publish your work in this journal}

The International Journal of General Medicine is an international, peer-reviewed open-access journal that focuses on general and internal medicine, pathogenesis, epidemiology, diagnosis, monitoring and treatment protocols. The journal is characterized by the rapid reporting of reviews, original research and clinical studies across all disease areas.

\section{Dovepress}

A key focus is the elucidation of disease processes and management protocols resulting in improved outcomes for the patient.The manuscript management system is completely online and includes a very quick and fair peer-review system. Visit http://www.dovepress.com/ testimonials.php to read real quotes from published authors.

Submit your manuscript here: http://www.dovepress.com/international-journal-of-general-medicine-journal 